\title{
The Professional Needs of Clinical Practice Supervisors
}

\section{Clara Amador-Watson}

Ph. D. in Educational Policy

and Administration.

Associate Professor and Researcher,

National University, Department

of Teacher of Education, Los Angeles,

California (USA).

camadorw@nu.edu

\section{Joan P. Sebastian}

Ed.D. in Educational Administration. Professor and Researcher, National University, Department of Special Education, San Diego, California (USA). jsebastian@nu.edu

\section{Abstract}

This article outlines the principal findings of a study intended fundamentally to research the needs of clinical practice supervisors in terms of their professional development. An online survey was designed and sent to more than 400 supervisors who were asked to supply information on the type of support provided to candidates. The initial results of the study suggest there are three fundamental types of effective support: 1) classroom management; 2) design of classes; and 3) individualized study programs for students with disabilities. Three challenges were identified:1) gathering comments and observations from school supervisors; 2) not enough time for comments and observations; and 3) insufficient time for conversing with the candidate. The findings of this study suggest the need to develop a systematic approach to counseling and guidance, in addition to having support teams with different functions.

\section{Key words}

Teacher training, training, educational needs, teaching practice (Source: Unesco Thesaurus). 


\section{Necesidades de desarrollo profesional de supervisores de prácticas clínicas}

Resumen

Se presentan los principales hallazgos de una investigación cuyo objetivo central fue investigar las necesidades de desarrollo profesional de los supervisores de prácticas clínicas. Se diseñó una encuesta en línea, que se envío a más de 400 supervisores, en la cual se proporcionaba información sobre el tipo de apoyo que brindan a los candidatos.

Los resultados iniciales sugieren que hay tres tipos fundamentales de apoyo efectivo: 1. Manejo del salón de clase; 2. Diseño de clases, y 3. Programa individualizado de educación para estudiantes con discapacidades. Se identifican tres desafios: 1. Recolección de observaciones de supervisores de escuelas; 2 . Escasez de tiempo para las observaciones, y 3. Escasez de tiempo para conversar con el candidato.

Los hallazgos del estudio señalan la necesidad de desarrollar un enfoque sistémico para proporcionar la asesoría, al igual que contar con equipos de apoyo que tengan funciones diferenciadas.

\section{Palabras clave}

Formación de profesores, capacitación, necesidades educacionales, práctica pedagógica (Fuente: Tesauro de la Unesco).

\section{Necessidades de desenvolvimento profissional de supervisores de prática clínica}

\section{Resumo}

Este artigo apresenta os principais resultados de um estudo cujo principal objetivo foi pesquisar as necessidades de desenvolvimento profissional dos supervisores de prática clínica. Nós projetamos uma pesquisa online que foi enviada para mais de 400 supervisores a fim de fornecer informação sobre o tipo de apoio que prestam aos candidatos. Os primeiros resultados deste estudo sugerem que existem três tipos de apoio: 1) direção da sala de aula, 2) projeto de aula, 3) programa de educação individualizado para estudantes com discapacidade. A pesquisa identificou três desafios: 1) coleta de comentários de supervisores escolares, 2) falta de tempo para fazer as observações e 3) falta de tempo para conversar com o candidato.

Os resultados deste estudo indicam a necessidade de desenvolver uma abordagem sistêmica para aconselhar, bem como ter equipes de apoio com funções diferentes.

\section{Palavras-chave}

Formação de professores, formação, necessidades de educação, prática pedagógica (Fonte: Tesauro da Unesco). 


\section{Introduction}

California, like the rest of the nation, has experienced a chronically high demand for qualified teachers for every student in every classroom. Throughout the 1990s, California had a steeply increasing demand for teachers, due to growing enrollment, increasing retirements, and high attrition rates, especially for beginning teachers. In addition to its burgeoning pupil population and its-olderthan-average teaching force, California's teacher hiring needs were spiked by the state's 1996 class size reduction initiative, which reduced class sizes to 20 students in the early elementary grades. (Darling-Hammond, 2001, p. 28)

As a result of growing student enrollments, the class size reduction initiative, the increasing retirement age, and the high attrition rates during the first years of teaching, California saw a dramatic growth in the issuance of emergency permits and waivers. If the problem was not a labor market shortage, given the annual production of credentialed teachers in the state, two questions would remain: (a) Why was there a need to hire underqualified teachers; and (b) to what type of schools and students were these underqualified teachers being assigned?

The No Child Left Behind Act (NCLB) of 2001 is the most dramatic shift in federal education policy in this arena during the last 30 years of American education. In that law, the term "highly qualified" was explained as it pertained to currently employed teachers and teachers new to the profession. For the former group, the term was applicable to teachers who held full state certification and had not had certification or licensure requirements waived. For teachers new to the profession, the term was applicable to teachers who had completed a bachelor's degree and could show subject matter competence via rigorous state examinations involving multiple-subject (elementary teachers) or single-subject tests or other advanced academic degrees in the designated subject area (middle or secondary teachers). Failure to comply with these federal requirements could seriously impact schools in terms of their eligibility for Title 1 funds.

Since 1967, with the creation of the university internship program, the State of California has responded to the need to provide fully credentialed teachers for every student in the state by passing legislation authorizing the creation of alternative routes or pathways to earning a teaching credential. In 1983, district internship programs were originally created for single- subject credentials, but these programs were expanded in 1987 to include multiple-subject teaching credentials (CTC, 1996). In Meeting the Highly Qualified Teachers Challenge (2002), a report issued by the U.S. Department of Education, the authors argued that alternative routes to teacher certification are able to streamline the process of certification and to assist qualified candidates in entering the teaching profession more quickly. The authors support this statement as it affects California.

A study conducted by Mithell and Romero (2010) further reveals an explanatory framework to better understand how internship programs operate in California. According to the study, there is a typology of intern programs that are classified in response to their institutional orientation for providing services in teacher preparation and credentialing: 1) Type A - School Oriented Traditional: Characterized as programs seeking to integrate intern programs into current teacher preparation that is able to respond to district needs; 2) Type B - School Oriented Local Culture: Characterized by socializing or adapting interns to the local educational agency's institutional norms for teaching and employment; 3) Type C - Candidate Oriented Traditional: Characterized by multiple delivery options, multiple access points and competitive cost-effectiveness; and 3) Type D - Candidate Oriented Intensified Training: Characterized by intensification of training and quality teaching for institutional reputations. (p. 377)

In California, alternative teacher certification is acquired either through university or district internship programs. An internship program for professional teacher preparation is defined as a period of one to two years of professional preparation, while the candidate is gainfully employed as a full-time teacher during all or part of the preparation program. Candidates assume full-time 
teaching responsibilities as the "teacher of record," after completing the pre-service requirements (120 clock hours) as stipulated by the credential recommending institution and the Commission on Teacher Credentialing.

In California, the Commission on Teacher Credentialing (CTC) has established the California Standards for the Teaching Profession (CSTP) and program standards for the effectiveness of internship programs, so that candidates need to complete pre-service requirements, coursework and clinical practice.

According to McKibbin (1998), in the CTC, four important factors distinguish internships from traditional programs:

(a) Internships have a pragmatic orientation, as they are focused primarily on the needs of interns in learningto-teach contexts;

(b) internships are market sensitive, inasmuch as they prepare teachers for high-need fields and high-need locations;

(c) interns learn by doing, with highly correlated preparation through the completion of a professional development plan;

(d) interns' own learning and evaluation are performance driven, based on their students' overall learning and achievement.

The university and district internship programs share key characteristics, as they prepare teachers for hardto-staff schools. First, both alternative certification routes seek candidates who may not otherwise become teachers. Second, both internship programs provide districts with interns engaged in highly supported professional preparation programs or plans. Third, both internship programs have developed a strong network of support and supervision services for enrolled interns (McKibbin, 1998). Internships in California meet the same state requirements and standards expected of more traditional teacher preparation programs; however, there is a great deal of variation in how the programs are designed, delivered, and implemented (McKibbin, 2001).

\section{Alternative Certification Programs}

Alternative certification programs allow candidates to complete their teacher preparation program while actively employed as a teacher of record in a K12 public school setting. Even though there is a great deal of variation in program design and structure, according to Mckibbin (2001), all alternative certification programs share the following characteristics:

1. Pragmatic Orientation: Candidates are asked to acquire new knowledge and to apply it to real life contexts within teaching positions, as teachers of record in K12 schools.

2. High-need Fields and Locations: Candidates are offered employment in high-need fields and at hard-to-staff locations. Most alternative certificate candidates are employed in teaching positions at schools where there is a documented shortage for a particular subject-matter such as math, science and/ or English. This is because the school is regarded as a hard-to-staff institution, given its demographics, level of poverty, level of violence, and/or remoteness.

3. Learning by Doing: In line with this principle, candidates are afforded consistent opportunities to understand, internalize and apply their newly acquired practitioner-level knowledge to real and immediate settings of professional practice, such as their classrooms. This environment for applied learning is most conducive to helping interns determine what works and what does not work on a daily basis.

4. Professional Learning is Performance-driven: Teaching performance drives professional learning for candidates in alternative certificated programs. What students learn, how much they learn, and how students demonstrate their learning takes place in the context of classroom teaching and learning. Historically, both traditional and alternative routes to teacher certification have encountered different types of challenges when providing quality teacher preparation programs. According to Barnett Berry, Diana Montgomery and Jon Snyder (2008), both programs face the following challenges: 
Challenges Faced by Traditional Pathways to Certification:
a. Difficulty in attracting high performing and/or mi- nority candidates;
b. Lack of access to exemplary teachers and teaching;
c. Failure to respond institutionally to identified short- age areas such as science, math, special education, and English language learners;
d. Limited infrastructure to provide induction support for graduating candidates once they begin teaching;
e. Lack of accountability for the effectiveness of graduates.

Challenges Faced by Alternate Pathways to Certification:
a. A consolidated curriculum that does not address teaching for diversity;
b. Insufficient clinical practice prior to becoming a teacher of record;
c. Few opportunities to learn content and subject-mat- ter -specific pedagogy simultaneously;
d. Preparation of teachers for a local context or a limi- ted, highly prescriptive curriculum;
e. Lack of accountability for the effectiveness of graduates.

In the area of clinical practice, traditional pathway programs have been unable to provide a strong infrastructure of induction support for newly-gradated candidates as soon as they begin teaching. On the opposite end, alternate pathway programs have not always provided enough clinical practice prior to becoming a teacher of record. It is precisely in the area of clinical practice that both routes to certification continue to experience important and unresolved challenges, as candidates need to develop knowledge in multiple areas of teaching performance and practice.

\section{Mentoring Candidates in Traditional Preparation Programs}

In teacher preparation, candidates need to have robust mentors from whom to learn and with whom to learn as they journey through their Learning to Teach continuum. Traditionally, certified candidates benefit from the support provided by mentors who usually are certificated and experienced in the same subject matter. Oftentimes, these mentors assume these responsibilities above and beyond their regular teaching assignments for the year. Skillful mentoring requires consistent communication, regular opportunities for conferencing, planned observation times, and professional availability. This professional availability (skills, will and availability) is understood as the access to a mentor and the maintenance of a relationship between mentor and mentee filled with opportunities to learn professionally. If a mentor is not available to the candidate, mentoring only happens as a requirement for compliance and not as a reality for the teacher candidate. Effective mentors need to demonstrate professional knowledge of the subject when supporting candidates (Smith \& Ingersoll, 2004); they need to develop a coaching relationship free of value judgment when relating to beginning teachers (Lee et al., 2006; Babione \& Shea, 2005); they need to be strategic and responsive to new teachers' needs (Smith, 2005); and, lastly, mentors need to create an emotional relational space with the candidate where trust and respect may grow for professional learning to take place over time (Lee et al., 2006; Loeffler, 2004).

\section{Mentoring Candidates in Alternate Routes to Certification Programs}

Clinical practice is defined as the continuity of field-based experiences where candidates are expected to apply, revise and reflect on their teaching practice in order to meet state licensing requirements conducive to a teaching credential for public schools.

Research on teacher training, beginning teacher training and induction suggests the need to provide strong mentoring for candidates as a measure of quality support and teacher effectiveness. The importance of mentoring beginning teachers has been discussed and explored extensively (Conway, Hansen \& Schulz, 2004; West, 2002; Darling-Hammond \& Berry, 1999). How it develops 
the knowledge base of beginning teachers (Turley, Powers, \& Nakai, 2006; Everston \& Smithey, 2000) has been researched as well, and the extent to which mentoring is critical for those candidates who do not follow a traditional route of teacher preparation is of major significance. In the latter case, candidates require mentoring in multiple and complex ways, since they are "learning by doing". Consequently, their need for applied knowledge is more acute than the needs of candidates who are not completing their clinical practice as teachers of record. According to Smith \& Evans (2008), mentoring takes place across alternate route programs that can be identified as: a) emergency routes; b) summer intensives; and c) university-based programs. Each program is compared to the others, based on the amount of preparation provided prior to teaching. In their own words, Smith and Evans (2008) indicate:

The university-based programs promote the use of mentors to support

the teacher's initial experiences, including the use of university supervisors

and school-based mentors... The urgent call for mentors has not been

matched, however, with a commitment to provide every alternate route

(AR) teacher with a dedicated and trained mentor. (pg. 252)

In alternative certification programs, candidates may experience support from a university-based support provider and a site support provider who work consistently together. However, these support providers sometimes fail to communicate with each other on a regular basis, providing disconnected feedback to the candidate. Occasionally, support is either not provided consistently by both support providers, or is only rarely provided by one support provider, if at all. Variations on the level of support provided, the frequency of support granted, the type of support provided, and the ways in which the candidate makes sense of it all are lenses of analysis that help us to understand how to best offer support for candidates to become effective teachers moving forward.

Supporting professional learning for effective teachers incorporates five areas of knowledge and practice (Smith \& Evans, 2008):
1) Logistical and Procedural Knowledge: Alternate route (AR) candidates need to have immediate and unrestricted access to everyday operational and procedural knowledge that ranges from understanding their daily schedule, to securing supplies and accessing resources such as textbooks and technology, permission for field trips, use and application of grading software, and knowing what is expected for student dismissal. Schools function as micro-cultural communities of practice and the candidate, as a teacher of record, needs to be socialized quickly on what are considered to be socially acceptable and non-acceptable regulations and procedures for their school site;

2) Instructional Knowledge: Candidates need to have a frame of reference for instructional design and planning anchored in both their credentialing coursework and their own recent teaching experiences. Each school may adopt a lesson-plan design that is somewhat different from models presented and analyzed at the university level. Candidates need mentoring support to make sense of the lesson design models presented to them in the university and the concrete lesson design models requested and utilized for teaching performance appraisal by their site administrators. In some instances, there may be a discrepancy between the two models; thus, candidates need the support of their mentors to make strategic decisions about their use and the implementation of lesson designs in response to their students in real time;

3) Conceptual Knowledge: As teachers of record, AR candidates are responsible for teaching content as soon as they are assigned to their classrooms. Each subject, be it mathematics, science, history or physical education, contains discipline-specific principles that are best aligned with certain pedagogical practices. Mentoring is needed to support and present 
subject- matter in the most comprehensible and developmentally appropriate way, depending on students' level of intellectual, emotional and social maturity;

4) Psychological and Emotional Knowledge: As new and beginning teachers, AR candidates oftentimes find themselves managing multiple tasks that compete for their attention simultaneously. The challenges interns face include, but are not limited to, the ability to establish priorities by managing competing demands from students, parents, peers, administrators and college professors and/or clinical practice supervisors. At times, internsfeelthat theyarenotableto navigateefficiently the three environments that intersect in their lives: university, school and home. Mentors or support providers are uniquely positioned to provide the psy chological and emotional support that reaffirms the candidate in his/her ability to multitask, organize informationfor different purposes,strategizeand prioritize, and to be emotionally present and responsive to oneself and to others; and

5) Philosophical Knowledge: How to teach can only be internalized and justified when we know why we teach the way we teach. At times, AR candidates find themselves making instructional and/or assessment decisions for students without an anchored understanding of the rationale justifying those decisions, given the immediate relevancy of knowing what to do and how,- but not why. This, in turn, creates a vacuum of understanding that, if unchecked, provides for a lack of congruency in teaching practice over time. Support providers are key to assisting candidates, as they fully understand the implications for teaching and learning that stem from their own practice in the area of differentiated instruction, in the area of differentiated assessment, and so on. Support is best provided through a combination of observation opportunities and communication that allows providers to frame areas of practice and belief about practice, as they encourage interns to become more cognizant and reflective about their work with students.

According to Berry, Daughtrey and Wieder (2010), professional learning for teachers takes place when teacher-led experiences are selected by individuals and groups based on needs related to the subjects and students they teach, when opportunities are provided for teachers to be both learners from and teachers of their peers, and when there is ongoing participation in long term professional development initiatives. Additionally, beginning teachers or newly credentialed teachers learn best in highquality, clinically intensive preparation programs, regardless of the path - traditional or alternate routes (Berry, Daughtrey \& Wieder, 2010). In their view, "the most successful programs will seek to extend learning and clinical times for trainees to the greatest extent possible, offer training in diverse pedagogical skills and rich content, and provide opportunities to apply such information in real classrooms" (pg 9). In this context, clinical practice experiences need to be designed so as to provide ample and intense opportunities for learning, mentoring and reflection on the applied knowledge to teaching practice and performance. In California, most university-based internship programs reflect these strong program characteristics, affording candidates robust and continuous support for professional growth.

\section{National University Internship Program}

At the National University, which is the second largest private, non-profit university in the State of California, the University Internship Teacher Education Program prepares candidates for multiple-subject ( $\mathrm{K}-8$ grades) and singlesubject (9-12 grades) credentials to teach in public schools. Additionally, the Special Education Program prepares candidates to work with students who have mild/moderate disabilities and moderate/severe disabilities.

The Teacher Education Internship Program is accredited by the Commission on Teacher Credentialing (CTC) and has a current enrollment in both preparation programs of approximately 800 candidates statewide. In order to become an eligible intern at the National University, candidates need to provide proof of completion of a bachelor's 
degree, subject matter competence as per the credential sought, and proof of an offer of employment in a public school setting. Once these requirements are verified, the candidate is required to complete the CTC approved preservice requirements comprised of 120 clock hours of work in the areas of Classroom Management, Content Area Literacy, English Language Development and Developmentally Appropriate Practices. At that point, the intern needs to complete a screening interview protocol in order to become eligible for a two-year university internship credential.

Once a university internship credential has been secured, interns need to complete a rigorous program that combines both coursework and clinical practice (See Appendix A and Appendix B) so as to become eligible for a preliminary teaching credential in multiple subjects or a single subject, or a credential as a special education teacher.

Clinical practice combines an internship seminar with the internship clinical practice cycle. The latter is designed to provide a system for a more structured assessment and evaluation of the intern's teaching performance at the end of the eight-month cycle of clinical practice for teacher education candidates and a six-month cy cle for special education candidates. Thus, the ongoing and formative assessment of practice is clearly linked to the final and summative evaluation of teaching practice, through formal assessments administered after the second and the eighth month of clinical practice. The university support provider will assess and evaluate the intern's performance, using the Assessment and Evaluation of Intern Teaching Performance, with timely and ongoing input provided by the site support provider. The intern will receive this assessment at the end of his/her second month, so as to provide baseline data on the Intern's demonstration of the TPEs, and again at the end of the eighth month to ensure the candidate demonstrates visible growth and satisfactory performance. In our Special Education Program, this assessment occurs three times during clinical practice. Satisfactory performance will be demonstrated by visible growth from the beginning to the end of the internship clinical practice cycle, with adequate application and integration of the Teaching Performance Expectations into classroom practice. Interns receive a passing grade when their performance scores three or above in the summative and final assessment and in the evaluation of performance at the end of the eighth month. This assessment is intended to be cumulative over a period of time.

Teacher education clinical practice is structured as follows:

\section{Figure 1. Teacher Education Internship Program}

\begin{tabular}{|c|c|c|}
\hline & $\begin{array}{l}\text { Multi-Subject Candidates } \\
\text { (K-8 grades) }\end{array}$ & $\begin{array}{l}\text { Single-Subject Candidates } \\
\text { (9-12 grades) }\end{array}$ \\
\hline $\begin{array}{l}\text { Teacher Education } \\
\text { Internship Clinical Practice }\end{array}$ & $\begin{array}{l}\text { Thirty- two documented } \\
\text { observation reports }\end{array}$ & $\begin{array}{l}\text { Thirty-two documented } \\
\text { observation reports }\end{array}$ \\
\hline $\begin{array}{l}\text { University } \\
\text { Support Provider (USP) }\end{array}$ & $\begin{array}{l}\text { 4/6 Other contacts (email, phone } \\
\text { conferencing, face-to- face meetings) } \\
12 / 16 \text { In-class observations } \\
* * * * * * * * * * * * * * * * * * * * * * * \\
8 / 12 \text { Documented lesson plans }\end{array}$ & $\begin{array}{l}\text { 4/16 Other contacts (email, phone conferencing, } \\
\text { face-to- face meetings) } \\
12 / 16 \text { In-class observations } \\
* * * * * * * * * * * * * * * * * * * * * \\
8 / 12 \text { Documented lesson plans }\end{array}$ \\
\hline Site Support Provider (SSP) & $\begin{array}{l}\text { 4/16 Other contacts (email, phone } \\
\text { conferencing, face-to- face meetings) } \\
12 / 16 \text { In-class observations } \\
* * * * * * * * * * * * * * * * * * * * * * * \\
8 / 12 \text { Documented lesson plans }\end{array}$ & $\begin{array}{l}\text { 4/16 Other contacts (email, phone conferencing, } \\
\text { face-to-face meetings) } \\
\text { 12/16 In-class observations } \\
* * * * * * * * * * * * * * * * * * * * * * \\
8 / 12 \text { Documented lesson plans }\end{array}$ \\
\hline
\end{tabular}

Special education clinical practice is structured somewhat differently.Candidates are required to have a minimum of six months of support from both the university support provider and the site support provider. 
Figure 2. Special Education Internship Program

\begin{tabular}{|l|l|l|}
\hline & $\begin{array}{l}\text { Mild/Moderate Candidates } \\
\text { (K-12) }\end{array}$ & $\begin{array}{l}\text { Moderate Severe Candidates } \\
\text { (K-12 grades) }\end{array}$ \\
\hline $\begin{array}{l}\text { Special Education } \\
\text { Internship Clinical Practice }\end{array}$ & $\begin{array}{l}\text { Twenty-four documented } \\
\text { observation reports }\end{array}$ & $\begin{array}{l}\text { Twenty-four documented } \\
\text { observation reports }\end{array}$ \\
$\begin{array}{l}\text { University } \\
\text { Support Provider (USP) }\end{array}$ & $\begin{array}{l}6 \text { formal lesson observations } \\
\text { informal consultation visits } \\
\text { months (two visits per month) }\end{array}$ & $\begin{array}{l}\text { 6 formal lesson observations } \\
6 \text { informal consultation visits } \\
12 \text { total classroom visits over six months (two visits } \\
\text { per month) }\end{array}$ \\
Site Support Provider (SSP) & $\begin{array}{l}\text { 12 total classroom visits, } \\
\text { classroom teaching }\end{array}$ & $\begin{array}{l}12 \text { total classroom visits, } \\
6 \text { visits should be to document classroom teaching }\end{array}$ \\
\hline
\end{tabular}

\section{Support Provided to National University Interns}

Site support providers (SSPs) are usually certificated teachers within same subject area or teaching assignment as the assigned intern, and they are recommended by the site administrator. University support providers (USPs) are usually retired educators who have expressed an interest in candidate supervision and are affiliated with the university as adjunct instructors or faculty.

Onsite support for interns is conducted by USPs and SSPs. Each intern receives a minimum of 16 coaching contacts from his/her SSP and 16 coaching contacts from his/ her USP. This amounts to a total of 32 coaching contacts over eight months. Special education interns receive 12 coaching contacts from their USP and 12 coaching contacts from their USP, for a total of 24 coaching contacts over six months. Coaching contacts can last from one to two hours when pre- and post-observation debriefings are included. Support is always responsive to the intern's needs and usually entails no fewer than 24 in-class visits and no more than eight out-of-class coaching contacts, such as focused email exchanges, phone conferences and/or inperson meetings. In the Special Education Program, six out of 12 contacts are provided as feedback or conferences that must occur in the classroom. All support is centered on the intern's needs and is thoroughly documented.

Site support providers (SSPs) receive one-on-one training in designated areas and provided by the USP. The regional full-time faculty is responsible for conducting university professional development at the local level, based on assessed needs.
Regional campuses provide professional development to university support providers (USP) at the beginning and at the end of internship clinical practice. Full-time and adjunct faculty and intern lead supervisors across the state receive ongoing training in a number of areas: specifically, Professional Development in Cognitive Coaching, the New Intern Intake Process, the New Intern Assessment and Evaluation Process, Program Components, Alignment of Internship to Teacher Performance Assessment (TPA), the Candidate Assistance Plan, the New Internship Handbooks and Virtual E-College Course Shells. Full-time faculty conduct scholarly research and present it at national and international conferences on alternative certification; i.e. the National Association of Alternative Certification (NAAC), the Association of Teacher Educators (ATE), the CA Intern Director's Conference, the International Council for Education on Teaching, and international education conferences in Hawaii, Washington DC, China, Portugal, Colombia and South Africa.

\section{Purpose of the Study}

The purpose of this study was to identify the professional development needs experienced by individuals who are currently serving as intern support providers (ISP). In their role as mentors and coaches, the study participants were asked about the support afforded to beginning tea- 
chers in public elementary and secondary schools. We were interested in understanding more about the kinds of support mentors and coaches provide for interns. Additionally, we wanted to identify the kind of support intern support providers feel they need in their role as mentors/coaches.

\section{Research Questions}

The following research questions guided our study:

1. What kinds of support do intern support providers supply to interns?

2. What kinds of support do intern support providers feel are most effective?

3. What are the greatest challenges experienced by interns in their clinical practice?

4. What are the challenges experienced by support providers?

5 What areas of professional development do intern support providers believe they need?

to perform their role better?

6. What delivery approaches to professional development would the support providers prefer?

\section{Methodology}

In order to answer the research questions listed above, an online survey was developed and distributed to support providers currently working with general education and special education interns. The survey was designed to gather critical information program developers felt was necessary to create an effective professional development model for intern support providers. The online survey used for this study has been included in the Appendices Section (Appendix C) and can be referenced to determine the number of questions, the type of questions and the content of the questions.

\section{Study Participants}

Over 900 candidates in both teacher education (general education) and special education were working in public schools as interns during the 2009-2010 academic year. Each intern was supported by two mentors or support providers; namely, a site support provider (SSP) and a university support provider (USP). Four hundred ninety-four intern support providers were identified to participate in the online survey across the State of California. The participants were a convenience sample of support providers selected because their demographic data were current in the university system and their current active status with the university was verified. Participants received an electronic invitation from the study authors to complete the online survey within a designated timeframe. The electronic invitation included an informed consent form, as part of the email invitation, indicating that participation in the study was voluntary and anonymous. The study was approved by the National University Institutional Review Board (IRB) prior to its implementation.

\section{Survey Instrument}

The survey instrument was designed to identify the critical information needed by the researchers. It addressed the aforementioned research questions in the following areas: (1) clinical practice program structure, (2) kinds and frequency of support provided, (3) professional development needed by support providers, and (4) models for delivering professional development. (See Appendix C)

The demographic information gathered in the area of program structure was designed to identify the number of respondents from each internship program: Teacher Education or Special Education. Respondents were asked to provide information on how many interns they had supported within the year, how many support visits they had made, how many actual classroom observations were completed, as well as how many consultative visits (non-classroom observation) were made. In the context of the support provided, the authors wanted to learn if the duration of the clinical practice experience required for interns was viewed as sufficient. Support providers also were asked about their perceptions of the effectiveness of the assessment instruments used to evaluate intern performance during clinical practice.

Following the general program structure, respondents were asked how often they provided 
support for interns in key teaching performance areas, as required by the California Standards for the Teaching Profession (CSTP). The standards assess teaching performance in the following areas: (1) providing access to subject matter, (2) assessing K-12 student learning, (3) engaging and supporting all learners, (4) planning instruction,(5)classroomorganizationandmanagement,and (6) professional conduct and dispositions. Along with these six teaching performance areas, support providers were asked to indicate the frequency of support in terms of targeted feedback specific to classroom observations, professional and technical support, consultation in other areas of practice, and assistance provided to interns for balancing the demands of the classroom with personal needs. This section ended with two open- ended questions: (1) Please list the top three most effective types of support you feel you have provided to interns. (2) Please list the top three cha-llenges you find in your intern support role.

The finaltwosections ofthesurveyasked respondents to rate the importance of specific professional development topics related to their role as intern support providers. And lastly, we asked the respondents to provide feedback on different models of professional development, including face-to-face meetings, a combination of face-to-face and online, and fully online or Internet-based professional development.

\section{Data Collection and Analysis}

Once the content of the survey was developed by the authors, the Office of Institutional Research and Assessment (OIRA) formatted the document and facilitated its electronic delivery to the sample of support providers identified statewide. In February 2010, the survey was emailed to the study participants and a reminder email was sent a week later. Data were compiled and analyzed by the OIRA, and provided to the authors for analysis. The software used for the text analysis was SPSS Text Analysis. For the quantitative responses, description analysis (e.g. frequency percentage, mean, topabox, and bottom 2 box) was used to analyze the data. For the qualitative analysis, the exhibit of conceptual categories was displayed, esta-blishing the correlational nature of relationships between categories, as per the frequency of such categories.

\section{Findings}

The survey results provided the authors with data that addressed the research question in each of the four main areas: (1) clinical practice program structure, (2) the kinds and frequency of support provided, (3) professional development needed by support providers, and (4) models for delivering professional development.A total of 495 electronic surveys were sent, 215 surveys were viewed online and 121 were completed for a $77 \%$ completion rate and a $24 \%$ overall response rate. Of all 121 replies, 53 respondents identified themselves as teacher education support providers and 68 were special education support providers. University support providers and site support providers responded to the survey, but the data are reported by program respondents (teacher education and special education).

\section{Clinical Practice Program Structure}

Program structure - the first section of the survey - addressed the number of interns supported, the frequency and type of support visits, the overall length of the clinical practice, and the effectiveness of the formative and summative assessment instruments. The following chart (Figure 3) illustrates the frequency of the support provided to interns in both programs. The variation in the number of visits reflects the difference in the length of each internship program. Teacher education interns receive support during eight months, while special education interns receive support for six months. Both site and university support providers visit each intern twice a month. How the time is used, be it for a formal observation or an informal consultation, depends on the individual needs of each intern, although monthly formal observations are required, as are two formal assessments for each intern in both programs. The first formal assessment is a formative assessment aimed at diagnosing the intern's needs; the second formal assessment is a summative and evaluative assessment of the intern's ultimateteaching performance. 
ISSN 0123-1294 | Educ.Educ. Vol. 14, No. 1 | Enero-abril de 2011 | pp. 137-165

Universidad de La Sabana | Facultad de Educación

Figure 3. Number of Interns, Types and Frequency of Support

\begin{tabular}{|c|c|c|}
\hline & Teacher Education TED & Special Education SPED \\
\hline & Mean & Mean \\
\hline $\begin{array}{l}\text { In the past three years, what is the average number } \\
\text { of interns you work with each year? }\end{array}$ & 2.82 & 5.75 \\
\hline $\begin{array}{l}\text { How many support visits do you complete for each } \\
\text { intern during their clinical practice? }\end{array}$ & 13.28 & 9.02 \\
\hline $\begin{array}{l}\text { How many classroom observations do you complete } \\
\text { on average per intern? }\end{array}$ & 13.09 & 7.57 \\
\hline $\begin{array}{l}\text { How many non-classroom observations do you } \\
\text { complete on average per intern? }\end{array}$ & 3.46 & 5.21 \\
\hline
\end{tabular}

We asked intern support providers to supply us with their assessment of the length of the clinical practice for each program. The data from this question are found in Figure 4. Overall, both groups of support providers felt the length of the clinical practice was appropriate for the respective programs.

Figure 4. Support Provider Assessment of the Length of Clinical Practice

(Teacher Education TED - Eight Months /

Special Education SPED - Six Months)

\begin{tabular}{|l|c|c|c|c|}
\hline \multirow{2}{*}{} & \multicolumn{2}{|c|}{$\begin{array}{c}\text { Teacher Education } \\
\text { TED }\end{array}$} & \multicolumn{2}{|c|}{$\begin{array}{c}\text { Special Education } \\
\text { SPED }\end{array}$} \\
\cline { 2 - 5 } & Count & $\begin{array}{c}\text { Column } \\
\text { N\% }\end{array}$ & Count & $\begin{array}{c}\text { Column } \\
\text { N \% }\end{array}$ \\
\hline Too long & 7 & $13.2 \%$ & 6 & $8.8 \%$ \\
\hline Appropriate & 43 & $81.1 \%$ & 54 & $79.4 \%$ \\
\hline Too short & 3 & $5.7 \%$ & 8 & $11.8 \%$ \\
\hline
\end{tabular}

We also asked support providers to respond to the following question: Is the current structure of the formative (diagnostic) and summative (final) assessment useful to your support role? Respondents were asked to evaluate this question based on a five-point Likert scale, with $1=$ Not at all useful and $5=$ Very useful.
Figure 5. Usefulness of the Formative and Summative Assessment Process

\begin{tabular}{|l|c|c|}
\hline & $\begin{array}{c}\text { Teacher } \\
\text { Education } \\
\text { TED }\end{array}$ & $\begin{array}{c}\text { Special } \\
\text { Education } \\
\text { SPED }\end{array}$ \\
\hline Top2Box (4 or 5) & $42 \%$ & $21 \%$ \\
\hline Bottom2Box (1 or 2$)$ & $13 \%$ & $40 \%$ \\
\hline Mean & 3.36 & 3.32 \\
\hline
\end{tabular}

The mean score is based on a five-point scale, with $1=$ Not at all useful and $5=$ Very useful.

Forty-two percent (42\%) of the TED support providers felt the instrument was "Useful" or "Very useful". In contrast, only $21 \%$ of the special education support providers felt the formative and summative assessment process was "Very useful" or "Useful". This difference may be due to the fact that special education support providers complete one extra assessment during the six-month clinical practice. This concern was expressed to the authors during a follow-up meeting, and the total number of assessments for the Special Education Program will be reduced to parallel the number of TED assessments. 


\section{Types and Frequency of Support}

The next section of the survey looked at the kinds and frequency of support provided for interns during their clinical practice. Respondents were asked to indicate how often (on a scale of one to five, "Never" to "Frequently") they provided support in specific areas related to the California Teaching Performance Expectations (TPE). Figure 4 illustrates the mean responses for each of the six TPE areas, for both the teacher education and special education internship programs. The data are reported by combining responses from the top two scales (Top2Box) and the bottom two scales (Bottom2Box).

Figure 6. Frequency of Support in Each of the Six Teaching Performance Expectations Areas

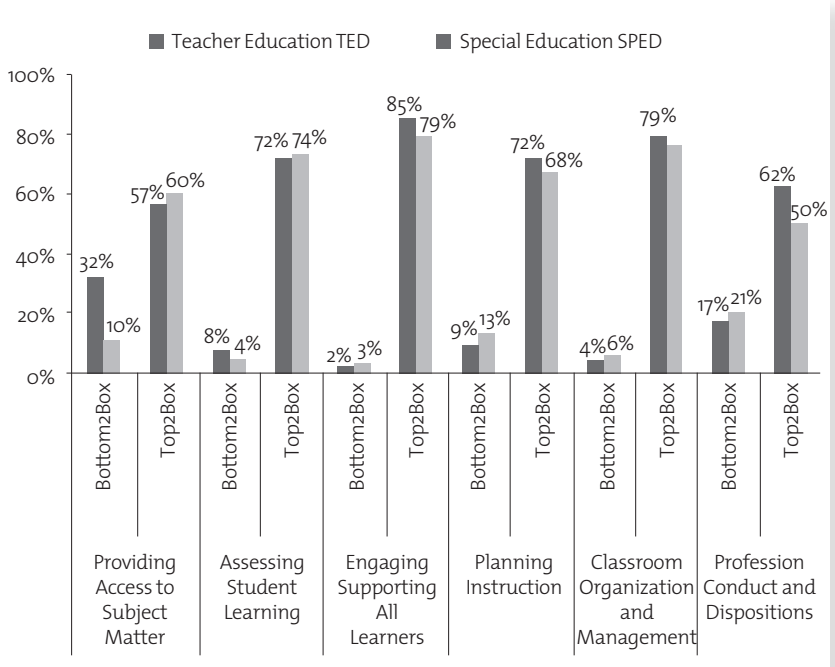

Top2Box $=4$ or 5 and Bottom 2 Box $=1$ or 2 Engaging and Supporting All Learners

The graph in Figure 6 provides insight into the areas where interns appear to need more intensive support. One TPE area that seems to pose challenges for interns is "Engaging and Supporting All Learners". This TPE refers to the need to involve all students in the P-12 classroom in meaningful learning activities, especially English-language learners and students with special needs. Another TPE area that was identified is "Organization and Management". This is an area where beginning teachers often struggle. In addition to the TPEs, we asked support providers to respond to four other areas where they would most likely provide support. Figure 7 identifies the areas where interns need assistance as well.

\section{Figure 7. Frequency of Support in Other Areas of Need}

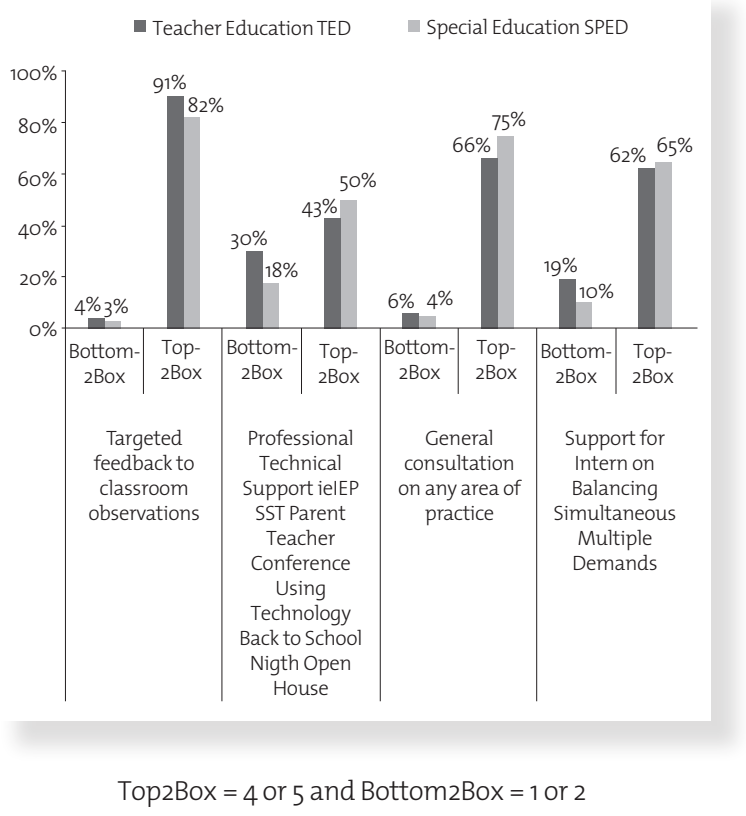

Professional Technical Support: i.e. EEP, SST Parent-teacher Conference, Using Technology, Back-to-School Night, Open House

General Consultation on Any Area of Practice Support for Interns on Balancing Simultaneous Multiple Demands

The clinical experience for interns includes both formal classroom observations and less formal, but equally important, consultation and support visits. The authors also wanted to know about the ratio of classroom and non-classroom visits during the clinical practice experience of university support providers. Figure 8 provides evidence that both groups of university support providers believe the ratio of classroom to nonclassroom visits is effective for their work with interns. The site support providers in SPED also feel the ratio is effective. The survey question for TED site support providers was incorrect; consequently, the data for this group are not reported. 
Figure 8. The Effectiveness of the Ratio of Classroom to Non-classroom Visits during Clinical Practice. (TED = 75\% Classroom $/ 25 \%$ Non-classroom; SPED $=50 \%$ Classroom/50\% Non-Classroom)

\begin{tabular}{|l|c|c|}
\hline & Teacher Education TED & Special Education SPED \\
\cline { 2 - 3 } & Mean & Mean \\
\hline TED University support providers $12 / 16$ & & 4.18 \\
SPED University support providers 6/12 & 4.17 & 4.03 \\
\hline SPED Site support providers 6/12 & & 4.03
\end{tabular}

The mean score is based on a five-point scale, with $1=$ Not at all effective and $5=$ Very effective.

To conclude this section on the kinds of support provided to interns, two open-ended questions were asked. They were designed to give the support providers an opportunity to address additional issues they have experienced in the field. In response to the first question: Please list the top three most effective types of supportyou feel that you have provided to interns, the most frequently mentioned areas were: classroom management (49 responses), feedback to candidates (28 responses), and lesson planning (23 responses). Another area noted frequently in an analysis of the responses was assistance provided with respect to the Individual Education Plan (IEP), which special education candidates are required to develop for students with disabilities.

The second open-ended question: Please list the top three challenges you find in your intern support role, yielded information that was more difficult to interpret. For example, the top three responses were focused on the ongoing dilemma of "time" - finding time to complete paperwork, lack of time for debriefing, and time to schedule observations. The authors are planning to complete a more in-depth analysis of the responses to identify more clearly the relationships between these ideas. The SPSS Text Analysis web of responses was created to analyze the relationships established among the categories derived from the participants' responses (See Appendix D).

\section{Professional Development Needs and Preferred Delivery Models}

Respondents wereasked to identifythe importance of specific content areas or topics for professional development, doing so on a scale of $1=$ Not at all important to $5=$ Very important. Figure 9 shows the mean responses on each of the five topics.

Figure 9. Importance of Topics for Professional Development

\begin{tabular}{|c|c|c|}
\hline & $\begin{array}{l}\text { Teacher Education } \\
\text { TED }\end{array}$ & $\begin{array}{l}\text { Special Education } \\
\text { SPED }\end{array}$ \\
\hline & Mean & Mean \\
\hline Roles, Responsibilities and Expectations & 4.09 & 4.34 \\
\hline California Standards for the Teaching Profession & 3.79 & 3.88 \\
\hline NU Implementation of the Teacher Performance Assessment (TPA) & 3.77 & 3.71 \\
\hline $\begin{array}{l}\text { Model for Coaching/Supporting Interns: Observations, Reports, Assessment and } \\
\text { Evaluation of Intern Teaching Performance Types }\end{array}$ & 4.09 & 4.13 \\
\hline Supporting Candidates with Challenges -CAP & 3.74 & 4.09 \\
\hline
\end{tabular}

The mean score is based on a five-point scale with $1=$ Not at all important and $5=$ Very important 
Two topics were identified as more important to the support providers responding to this question. The first topic; namely, "roles and responsibilities," suggests they were interested in obtaining more clarification and/or information about expectations for their role as support providers. The second topic area relates to specific mentoring and coaching skills, as well as strategies for observing and evaluating intern performance. Both of these topic areas became the focus of the first state-wide Intern Support Provider Workshop, which was offered in the Spring of 2010 by the National University.
Finally, in an effort to identify different ways to provide for professional development, we intern support providers were asked to indicate a preference for different ways of contributing to professional development. Figure 10 illustrates the support providers' preferences for professional development delivery models. The message was clear. Support providers prefer to participate in professional development in person, with a mean of 4.30 for face-to-face sessions and 3.40 for one-day regional support conferences.

Figure 10. Delivery Options for Professional Development

\begin{tabular}{|l|c|c|}
\hline & Teacher Education TED & Special Education SPED \\
\cline { 2 - 3 } & Mean & Mean \\
\hline Face-to-face sessions & 4.30 & 4.25 \\
\hline Online course (one week) & 2.43 & 2.72 \\
\hline Face-to-face, plus online course (Hybrid) & 2.79 & 3.35 \\
\hline Computer conference via Internet (synchronous Adobe Connect) & 2.45 & 3.07 \\
\hline Web-based intern support blog or threaded discussion & 2.51 & 2.97 \\
\hline One-day regional support provider conference & 3.40 & 3.65 \\
\hline
\end{tabular}

The mean score is based on a five-point scale with $1=$ Not at all important and $5=$ Very important.

\section{Discussion and Recommendations}

The purpose of this study was to identify the professional development needs experienced by individuals who are currently serving as intern support providers. To acquire a better understanding of these needs, we surveyed support providers and focused our inquiry on three main areas: (1) clinical practice program structure, (2) the kinds and frequency of support provided, (3) professional development needed by support providers, and (4) models for delivering professional development. The following sections provide an overview of what we have learned from support providers in each of these three areas. We conclude this report with a brief discussion of our plans for future research in this area.

\section{Structure of Clinical Practice}

In the first section of the survey, we asked several questions that provided information about the structure of clinical practice in both teacher education and special education. The survey respondents believe the structure of the clinical practice experience for intern candidates is effective in terms of their role as support providers. It also appears the implementation of the clinical practice experience in both teacher education and special education is loyal to the program integrity and design. In other words, the number of classroom visits and non-classroom contacts aligns well with the program expectations. 
On average,support providersinthe TED program support three interns per year and SPED support providers support close to six interns during the academic year. The variation in the number of interns supported is a reflection of the difference in the length of each of these experiences. In both TED and SPED programs, approximately $80 \%$ of the support providers felt the length of clinical practice was appropriate. This aligns with the current program structure and reaffirms the need for differential amounts of support provided to TED and SPED candidates. In California, most candidates seeking a Special Education Credential have already secured classroom-based experience as either a general education teacher or directly with students with disabilities, as a paraprofessional (aide in the classroom).

In the TED Program, $42 \%$ of the support providers felt the formative and summative assessments were useful or very useful; whereas, in special education, only $21 \%$ felt the same way about. Upon a further review of this finding, it was determined that three assessments are used currently, and this was viewed by support providers as redundant or excessive. This finding contributes to future program improvement by reducing the number of assessments from three to two.

\section{Support Provided to Interns}

We asked the survey respondents to tell us about how often, in what areas and in what ways they provided support for interns. In terms of teaching performance expectations, as designated by the California State Standards for the Teaching Profession (CSTP), both TED and SPED support providers indicated the areas where they provide the most support for interns were: 1) engaging students in learning, and 2) classroom organization and management. These data will inform future initiatives in both programs in areas such as the inclusion of additional coursework in "classroom management and organization" as part of the pre-service requirements to become an intern. Additionally, both programs have developed robust courses in the area of differentiated instruction and assessment.

In both TED and SPED programs, the type of support provided with the greatest frequency was "targeted feedbackto classroom observations". This finding further establishes the importance and relevance of immedia- te, on-demand debriefing based on observed teaching practice in the classroom. Thisfeedback allows support providers to be context-specific in their support, based on observed need. The next two areas where support was provided the most often evidence general consultation and affective support when dealing with multiple and competing demands for interns. The stress experienced by interns as they struggle to manage multiple demands in the classroom also is understood as psychological and emotional knowledge (Smith\& Evans, 2008) and is clearly an area where support should be and is provided by respondents.

In SPED, both USPs and SSPs found the number of classroom observations vs. the number of non-classroom observations to be effective, and so did the USPs for teacher education. However, the data for site support providers in TED was not accurate, due to an error contained in the survey item.

The open-ended questions provided a wealth of information for the authors. In response to the first question concerning the most effective types of support provided to interns, those mentioned most frequently were: 1) classroom management, 2) lesson and unit planning, and 3) IEP writing. The next most-reported areas of support included: 1) direct feedback on what works and what does not work, 2) effective teaching strategies, and 3) time management. And finally, in terms of effective types of support, the third most frequently mentioned areas were: 1) suggestions for pacing and transitioning, 2) management of time and stress, and 3) providing support and encouragement. As we look toward using this information, it will be important to tap into the knowledge and skills demonstrated by the support providers working with our interns. In this context, specific examples of effective support should be captured and shared with others as we work towards new and innovative professional development.

When support providers were asked to identify the top three challenges they face in their role, those most frequently mentioned were: 
1) getting observations from site support providers, 2) time to debrief after observation, and 3) time to do all the observations, while also holding down a full-time job (site support provider issue). The next most frequently mentioned challenges identified were: 1) interns' resistance to new strategies, 2) time for three-way conferences with the intern and SSP, and 3) time constraints on visits. The third most frequently mentioned challenges included: 1) too much paperwork, 2) communication with site support provider, and 3) arranging time to observe. This information provides the program coordinators with insight into the challenges experienced by support providers in both programs, especially with respect to time. Assistance with time management strategies would be an appropriate topic for future professional development.

\section{Professional Development}

The last section of the survey gathered feedback from respondents on their needs and preferences in terms of professional development. In both TED and SPED programs, support providers identified two topic areas of maximum importance: "Roles, Responsibilities" and "Expectations and Models for Coaching and Supporting Interns". These two topics speak to the design and implementation of our program, since expectations are constantly changing due to new state standards and new internal program demands. It is imperative that support providers first understand their role and the important expectations we have for them as they support our interns. In addition, as we begin to design professional development for support providers, effective models of coaching and mentoring need to be identified and provided for everyone working with interns. In response to this need, our departments have instituted statewide, so-called Annual Intern Support Provider Workshops to address these issues.

We also wanted to understand how we might deliver professional development to support providers who are located throughout the State of California and who support over 800 interns annually. We provided them with several different choices that included both in-person and technologically-enhanced kinds of delivery options. In both TED and SPED programs, the support providers' preferred modality for professional development is face-to-face sessions at the regional or state level. As noted above, we offered a statewide annual face-to- face workshop during the Spring of 2010 and intend to continue with additional regional opportunities throughout the year. Additionally, our university has a great deal of virtual offerings and, thus, we plan to supplement and enrich the onsite offerings with online offerings in the form of web based e-learning and technologically-enhanced professional learning for all support providers.

\section{Recommendations for Future National and International Research}

As the authors move forward with the knowledge we have gained from this initial survey, we plan to continue to explore the professional development needs of support providers. The data from this survey raised several interesting questions concerning how support is provided and what kinds of challenges support providers experience in their role. We plan to conduct a series of interviews and focus groups to identify these issues more clearly and to probe more deeply into the experiences of our support providers. Gathering these kinds of data over the full cycle of support also could provide us with insight into the development of the relationship between the support provider and the intern.

We also plan to follow up with the interns, using a similar survey to identify the kinds of support they need and how they believe they are being supported in the classroom. Besides surveying a large number of interns, we have plans to examine the development of beginning teachers as they move through an extended clinical experience as interns. This will be done through the use of a single case study approach. While time consuming, we feel the knowledge gained through this kind of study will provide us with new information and ways to enhance the experiences of both interns and support providers.

This research study is replicable to other national and international contexts where teachers 
are being prepared for initial licensing. In many countries, candidates to the teaching profession are asked to complete student teaching, residencies or internships, while completing their professional programs. Teacher education researchers may be able to use a similar design to better understand the structure of sustained support over time and the types of professional development that best equip clinical support providers. Conducting this type of inquiry will help others to systematize their understanding of useful support for teacher candidates in more complex and effective ways. At the institutional level, program improvement may result from this journey of inquiry into the quality of support, the frequency of support and the underlying rationale for support. At the national level, new teacher education policies can be informed by expectations of access, quality and rigor to sustained professional support for credential seeking candidates.

\section{References}

Babione, C., \& Shea, C. (2005). Special Education mentoring within the context of rural Schools. Rural Special Education Quarterly, 24 (2), 3-10.

Berry, B., Daughtrey, A., \& Weider, A. (2010). Preparing to lead an effective classroom: The role of teacher training and professional development programs. Teachers Network and the Centerfor Teaching Quality (CTQ); policy brief retrieved from the ERIC database.

Berry, B., Daughtrey, A., \& Weider, A. (2010). Teacher leadership: Leading the way to effective teaching and learning. Teachers Network and the Center for Teaching Quality (CTQ); policy brief retrieved from the ERIC database.

Berry, B., Montgomery, D., \& Snyder, J. (2008). Urban teacher residency models and institutes of higher education: Implications for teacher preparation. Center for Teaching Quality (CTQ), policy brief retrieved from the ERIC database.

California Commission on Teacher Credentialing (1996). The effectiveness of Districts' intern programs of alternative teacher certification in CA: A longitudinal study. Sacramento, CA: Author.

California Commission on Teacher Credentialing:http://www.ctc.ca/reports/BTSA_Intern_Technical Reports_23_ Oct_2007 PDF

Conway, C., Hansen, E., \& Schultz, A. (2004). Becoming a teacher: Stories of the first few years. Music Educators Journal, $91(1), 45-50$.

Darling-Hammond, L., \& Berry, B. (1999). Recruiting teachers for the 21st century. The foundation for educational equity. The Journal of Negro Education, 68 (3), 254-279.

Darling-Hammond, L., Lafors, J., \& Snyder, J. (2001). Educating teachers for California's future. Teacher Education Quarterly, 28 (1), 9-55. 
Everston, C., \& Smithey, M. (2000). Mentoring effects on protégés' classroom practice: An experimental field study. The Journal of Educational Research, 93 (5), 294-304.

Freistritzer, C., \& Chester, D. T. (2002). Alternative teacher certification. State-by-state analysis 2002. Washington DC: National Center for Education Information.

Ingersoll, R., \& Smith, T. (2004). Do teacher induction and mentoring matter? NASSP Bulletin, 88 (638), 28-40.

Lee, S., Theoharis, R., Fitsparick, M., Kim, K., Liss, J. M., Nix-Williams, T., Griswold, D. E., \& Walther-Thomas, C. (2006). Create effective mentoring relationships: Strategies for mentor and mentee success. Intervention in School and Clinic, 41 (4), 233-240.

Loeffler, M. H. (2004). The fine art of mentoring. Montessori Life, 16 (2), 23.

Mithell, D. E., \& Romero, L. (2010). The politics and practice of alternative certification. Educational Administration Quarterly, 46, 363-394.

McKibbin, M. (1988). Alternative certification in California. Teacher Education Quarterly, 15 (3), 49-59.

McKibbin, M. (2001). One size does not fit all: Reflections on alternative routes to teacher preparation in California. Teacher Education Quarterly, 28 (1), 133-149.

National Center for Alternative Certification: http://www.teach-now.org

Smith, M. V. (2005). Modern mentoring: Ancient lessons for today. Music Education Journal, 92 (2), 62-67.

Smith, E., \& Evans, C. (2008). Providing effective mentoring for alternate route beginning teachers. Teacher Educator, $43(4), 249-278$.

Turley, S., Powers, K., \& Nakai, K. (2006). Beginning teachers' confidence before and after induction. Action in Teacher Education, 28 (1), 27-39.

US Department of Education: http://www.teach.gov

US Department of Education-Office of Innovation and Improvement FY 2011. Transition to teaching: http:// www.2.edgov/programs/transitionteach/index.html

West, P. R. (2002). $21^{\text {st }}$ Century professional development: The job-embedded, continual learning model. American Secondary Education, 30 (2), 72-86. 


\section{APPENDIX A}

\section{TEACHER EDUCATION DEPARTMENT INTERNSHIP PROGRAM}

\section{COURSEWORK AND CLINICAL PRACTICE}

National University interns must complete the following coursework and fieldwork, as outlined below:

\begin{tabular}{|c|c|c|}
\hline \multicolumn{2}{|c|}{ Coursework } & Clinical Practice \\
\hline \multicolumn{2}{|c|}{$\begin{array}{l}\text { TED629l (eight months, once a month) } \\
\text { TED610 (eight weeks, once a week, plus a Final Exam/ } \\
\text { Project session) } \\
\text { HED602,EXC625,EDT608 co-requisites }\end{array}$} & $\begin{array}{l}\text { TED628I Internship - Clinical Practice } \\
\text { (Eight-month support/mentoring cy cle } \\
\text { Same for Multiple/Single Subject) }\end{array}$ \\
\hline Multiple Subject & Single Subject & $\begin{array}{l}\text { (Interns are required to complete coursework and fieldwork } \\
\text { simultaneously.) }\end{array}$ \\
\hline TED605 & TED605 & \\
\hline TED611 & TED611 & 16 visits by NUSP (or 2 visits per month) \\
\hline TED615 & TED615 & 16 visits by SSP (or 2 visits per month) \\
\hline TED621A & TED623 & A total of 32 visits must be verified on the Observation/Contact \\
\hline TED621B & TED624 & $\begin{array}{l}\text { Completion Form } \\
\text { (OCC-1) over the eight months }\end{array}$ \\
\hline TED622A & TED625A & \\
\hline TED622B & TED625B & \\
\hline
\end{tabular}




\section{APPENDIX B}

\section{SPECIAL EDUCATION DEPARTMENT INTERNSHIP PROGRAM}

National University special education interns must complete the following coursework and fieldwork, as outlined below:

\begin{tabular}{|c|c|}
\hline Coursework & Clinical Practice \\
\hline EXC 602A, Field Exp: Special Education; EXC 620 Behavior & EXC 685I Internship: Mild/Moderate Disabilities \\
\hline support; and TED 621B Language Arts Methods [courses & EXC 69ol Internship: Moderate/Severe Disabilities \\
\hline completed prior to beginning clinical practice] & (Six month support/mentoring cy cle. Same for both Mild/ \\
\hline EXC 655 I Intern Seminar (2 months) & Moderate and Mod/Severe) \\
\hline \multicolumn{2}{|l|}{ EXC 604 Exceptionally/Diversity } \\
\hline EXC 602B Inclusive settings & Interns are required to complete coursework and clinical \\
\hline TED 615 Foundations & practice at the same time. \\
\hline TED 611 Ed Psy ch & 12 Classroom visits by NU support provider (2 visits per \\
\hline HED 602 Health Ed & month) \\
\hline EDT 608 Computers in classrooms & 12 Classroom visits by site support providers (2 visits per \\
\hline EXC 630 Assessment & month) \\
\hline \multicolumn{2}{|l|}{ EXC 650 Collaboration } \\
\hline TED 621A/623 Lang Dev. Methods & A total of 24 visits must be documented over the six \\
\hline EXC 644/A Reading Methods \& Field -work & months. \\
\hline EXC 660/A Instruct of Mild/Moderate Learners \& Fieldwork & Candidates can apply for their preliminary Education \\
\hline EXC 665/A Instruct of Moderate/Severe Learners \& Fieldwork & Specialist Credential after all courses and clinical practice \\
\hline EXC 603A Exit Seminar & have been completed successfully. \\
\hline
\end{tabular}




\section{APPENDIX C}

\section{ONLINE SURVEY}

In completing this form, I understand the following:

- My participation is voluntary and I may refuse to participate in or I may withdraw from this study at any time without any negative consequences.

- My answer will become part of the university records.

- In compliance with the Family Educational Rights and Privacy Act (FERPA), the provided information will not be released without my separate consent and all identifiable information will be protected to the limits allowed by law.

- If I have any questions, comments or concerns about the study or the consent process, I may write to or call the Office of Institutional Research and Assessment at the National University.

11255 North Torrey Pines Road

La Jolla, CA 92037

This study was approved by the NU Internal Review Board. By submitting the following information, I acknowledge that I have read and understand the consent form.

Please select your primary area of support.

1. Teacher Education (TED)

2. Special Education (SPED)

Clinical Practice Program Structure

\begin{tabular}{|l|c|}
\hline & Teacher Education \\
\hline In the past three years, what is the average number of interns you work with each year? & $\square$ \\
\hline How many support visits do you complete for each intern for their clinical practice? & $\square$ \\
\hline How many classroom observations do you complete on average per intern? & $\square$ \\
\hline How many non-classroom observations do you complete on average per intern? & $\square$ \\
\hline
\end{tabular}


What is your assessment of the length of clinical practice for interns?

\begin{tabular}{|l|c|c|c|}
\hline & Toolong & Appropriate & Too short \\
\hline Teacher Education (TED) - Eight Months & $\square$ & $\square$ & $\square$ \\
\hline
\end{tabular}

Clinical Practice Program Structure

\begin{tabular}{|l|c|}
\hline & Special Education \\
\hline In the past three years, what is the average number of interns you work with each year? & $\square$ \\
\hline How many support visits do you complete for each intern for their clinical practice? & $\square$ \\
\hline How many classroom observations do you complete on average per intern? & $\square$ \\
\hline How many non-classroom observations do you complete on average per intern? & $\square$ \\
\hline
\end{tabular}

What is your assessment of the length of clinical practice for interns?

\begin{tabular}{|c|c|c|c|}
\hline & Toolong & Appropriate & Too short \\
\hline Special Education (SPED) - Six Months & $\square$ & $\square$ & $\square$ \\
\hline
\end{tabular}

Is the current structure of the Formative (Diagnostic) and Summative (Final) Assessment useful to your support role?

1 - Not at all useful

2

3

4

5 - Very useful 
Please indicate how often you provide support for the following teaching performance areas.

\begin{tabular}{|l|c|c|c|c|c|}
\hline & $\begin{array}{c}1 \\
\text { Never }\end{array}$ & 2 & 3 & 4 & 5 \\
\hline Providing Access to Subject Matter & $\square$ & $\square$ & $\square$ & $\square$ & $\square$ \\
\hline Assessing Student Learning & $\square$ & $\square$ & $\square$ & $\square$ & $\square$ \\
\hline Engaging \& Supporting All Learners & $\square$ & $\square$ & $\square$ & $\square$ & $\square$ \\
\hline Planning Instruction & $\square$ & $\square$ & $\square$ & $\square$ & $\square$ \\
\hline Classroom Organization and Management & $\square$ & $\square$ & $\square$ & $\square$ & $\square$ \\
\hline Profession Conduct and Dispositions & $\square$ & $\square$ & $\square$ & $\square$ & $\square$ \\
\hline
\end{tabular}

Please list other areas of teaching performance where you provide support not listed above.

Please indicate the frequency of the support you provide to interns for the following.

\begin{tabular}{|l|c|c|c|c|c|}
\hline & $\begin{array}{c}1 \\
\text { Never }\end{array}$ & 2 & 3 & 4 & 5 \\
\hline Targeted Feedback to Classroom Observations & $\square$ & $\square$ & $\square$ & $\square$ & $\square$ \\
\hline $\begin{array}{l}\text { Professional \& Technical Support (i.e. IEP, SST, } \\
\text { Parent-teacher Conference, Using Technology, Back } \\
\text { to School Night, Open House) }\end{array}$ & $\square$ & $\square$ & $\square$ & $\square$ & $\square$ \\
\hline $\begin{array}{l}\text { General Consultation on Any Area of Practice } \\
\text { Support for Interns on Balancing Simultaneous }\end{array}$ & $\square$ & $\square$ & $\square$ & $\square$ & $\square$ \\
\hline Multiple Demands & $\square$ & $\square$ & $\square$ & $\square$ & $\square$ \\
\hline
\end{tabular}


Please list other areas of support that are not noted above.

Assess the effectiveness of the ratio of classroom to non-classroom observations during clinical practice. TED (75\% Classroom / 25\% Non-classroom Observations)

\begin{tabular}{|l|c|c|c|c|c|}
\hline & $\begin{array}{l}1 \\
\text { Not at all effective }\end{array}$ & 2 & 3 & 4 & $\begin{array}{c}5 \\
\text { Very effective }\end{array}$ \\
\hline TED University support providers (12/16) & $\square$ & $\square$ & $\square$ & $\square$ & $\square$ \\
\hline TED Site support providers (6/12) & $\square$ & $\square$ & $\square$ & $\square$ & $\square$ \\
\hline
\end{tabular}

Assess the effectiveness of the ratio of classroom to non-classroom observations during clinical practice. SPED (50\% Classroom / 50\% Non-classroom Observations)

\begin{tabular}{|l|c|c|c|c|c|}
\hline & $\begin{array}{l}1 \\
\text { Not at all effective }\end{array}$ & 2 & 3 & 4 & $\begin{array}{c}5 \\
\text { Very effective }\end{array}$ \\
\hline SPED University support providers (6/12)) & $\square$ & $\square$ & $\square$ & $\square$ & $\square$ \\
\hline SPED Site support providers (6/12) & $\square$ & $\square$ & $\square$ & $\square$ & $\square$ \\
\hline
\end{tabular}

Please explain why:

\section{Support Needs}

Please list the three most effective types of support you feel you have provided to interns.

1

2

3 
ISSN 0123-1294 | Educ.Educ. Vol. 14, No. 1 | Enero-abril de 2011 | pp. 137-165

Universidad de La Sabana | Facultad de Educación

Please list the top three challenges you find in your intern support role.

1

2

3

Professional Development

Based on your needs as an intern support provider, please rate the importance of the following areas or topics for professional development.

\begin{tabular}{|l|c|c|c|c|c|}
\hline & $\begin{array}{c}1 \\
\text { Not at all } \\
\text { important }\end{array}$ & 2 & 3 & 4 & $\begin{array}{c}5 \\
\text { Very } \\
\text { important }\end{array}$ \\
\hline Roles, Responsibilities and Expectations & $\square$ & $\square$ & $\square$ & $\square$ & $\square$ \\
\hline California Standards for the Teaching Profession & $\square$ & $\square$ & $\square$ & $\square$ & $\square$ \\
\hline NU Implementation of the Teacher Performance Assessment (TPA) & $\square$ & $\square$ & $\square$ & $\square$ & $\square$ \\
\hline $\begin{array}{l}\text { Model for Coaching/Supporting Interns (Observations, Reports, } \\
\text { Assessment and Evaluation of Intern Teaching Performance, Types of } \\
\text { Support...) }\end{array}$ & $\square$ & $\square$ & $\square$ & $\square$ & $\square$ \\
\hline Supporting Candidates with Challenges (CAP) & $\square$ & $\square$ & $\square$ & $\square$ \\
\hline
\end{tabular}

Please list other areas of professional development that are not noted above. 
Professional Development

Based on your needs as an intern support provider, please rate the importance of the following areas or topics for professional development.

\begin{tabular}{|l|c|c|c|c|c|}
\hline & $\begin{array}{c}1 \\
\text { Notat all } \\
\text { important }\end{array}$ & 2 & 3 & 4 & $\begin{array}{c}5 \\
\text { Very } \\
\text { important }\end{array}$ \\
\hline Face-to-face sessions & $\square$ & $\square$ & $\square$ & $\square$ & $\square$ \\
\hline Online course (one week) & $\square$ & $\square$ & $\square$ & $\square$ & $\square$ \\
\hline Face-to-face, plus online course (Hybrid) & $\square$ & $\square$ & $\square$ & $\square$ & $\square$ \\
\hline Computer conference via Internet (synchronous Adobe Connect) & $\square$ & $\square$ & $\square$ & $\square$ & $\square$ \\
\hline Web-based intern support blog or threaded discussion & $\square$ & $\square$ & $\square$ & $\square$ & $\square$ \\
\hline One-day regional support provider conference & $\square$ & $\square$ & $\square$ & $\square$ & $\square$ \\
\hline
\end{tabular}

Please add other suggestions for the delivery of professional development.

Please add any other comments about your experience as a National University support provider. 
ISSN 0123-1294 | Educ.Educ. Vol. 14, No. 1 | Enero-abril de 2011 | pp. 137-165

Universidad de La Sabana | Facultad de Educación

\section{APPENDIX D}

\section{TEXT ANALYSIS (SPSS)}

Most Effective Support Type Provided to Interns:
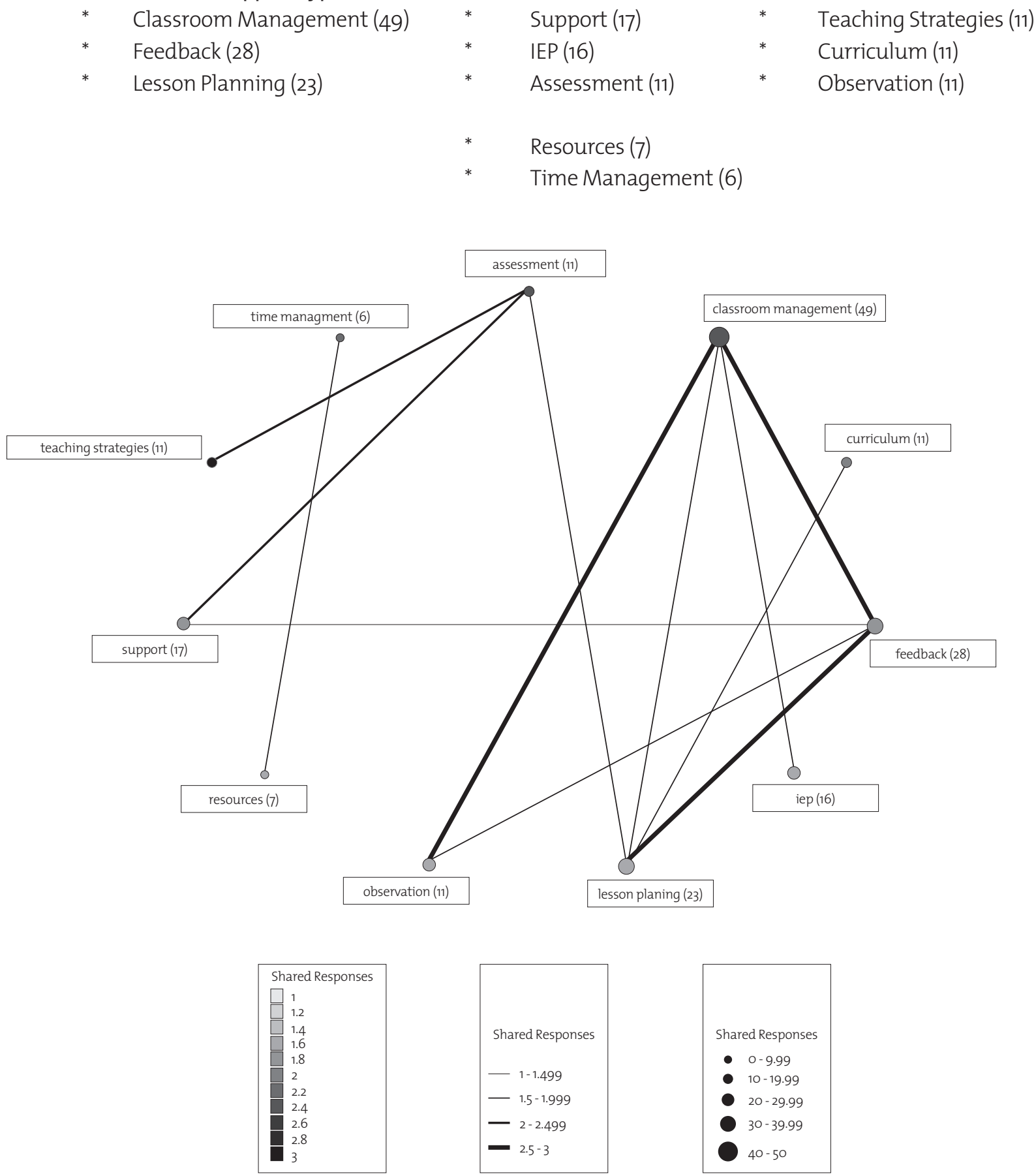


\section{APPENDIX D (Cont.)}

\section{TEXT ANALYSIS (SPSS)}

\section{Challenges in Intern Support Role:}

* Time (58)

* Intern (35)

* $\quad$ Lack (22)

* Observation (15)

* $\quad$ Students (12)
* Teachers (12)

* Support (11)

* Paperwork (11)

* $\quad$ Form (6)

* Communication (4)

* Teaching Experiences (2)

* Behavior Problem (2)
* $\quad$ Classroom Management (4)

* $\quad$ Assessment (4)

* Lesson Planning (3)

* Curriculum (3)

Planning (3)

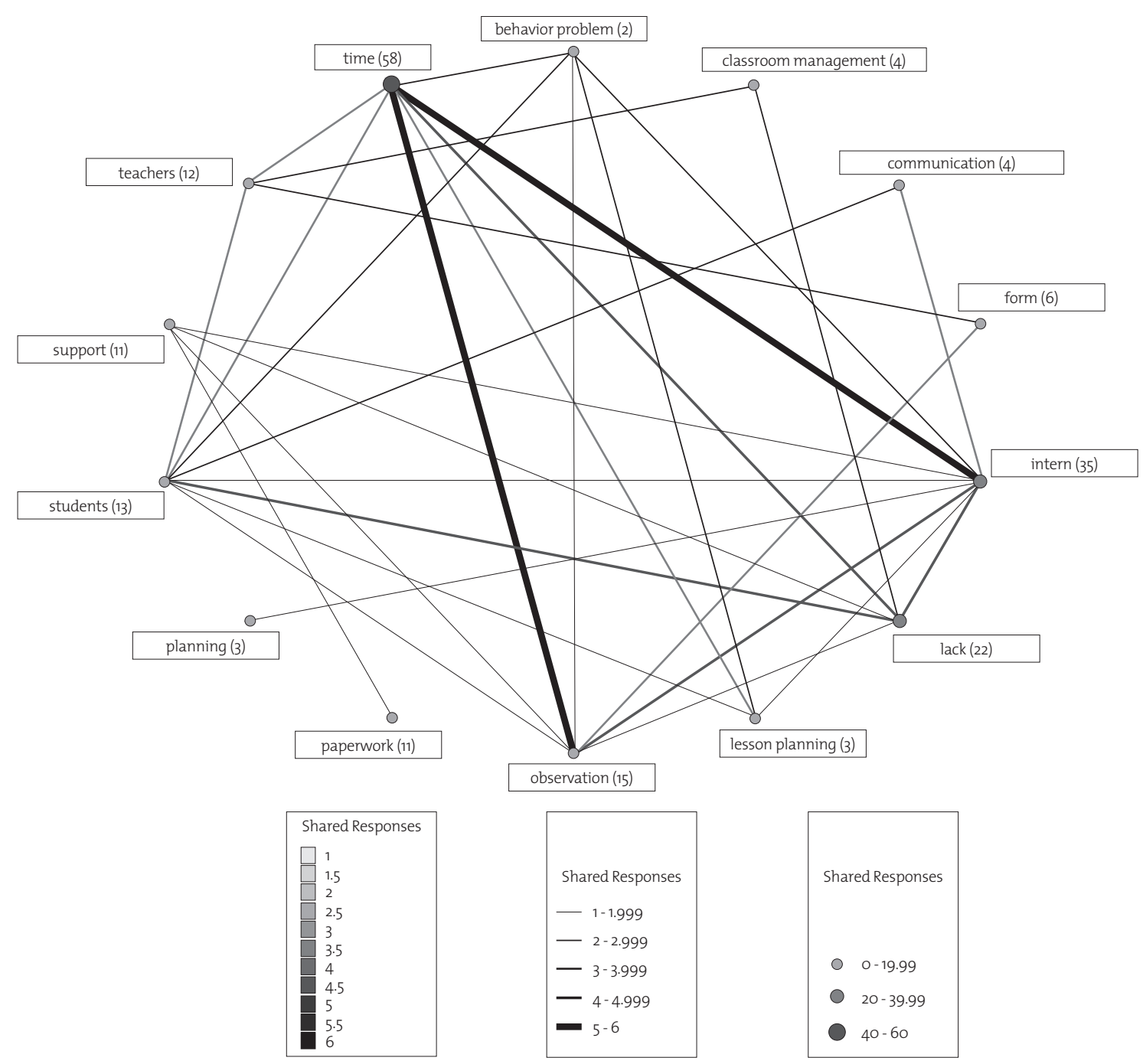

